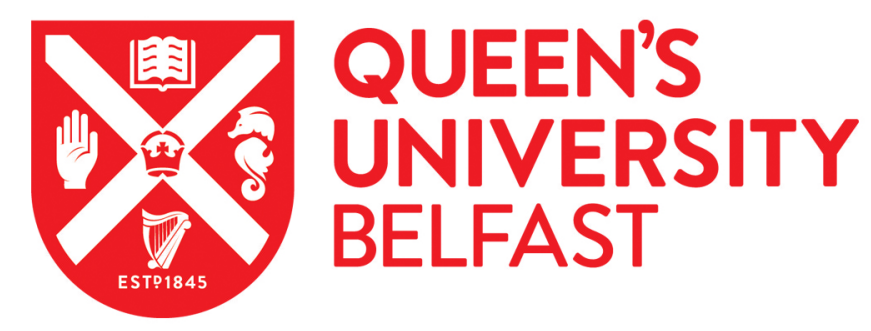

\title{
Sense making of Brexit for Economic Citizenship In Northern Ireland
}

Brownlow, G., \& Budd, L. (2019). Sense making of Brexit for Economic Citizenship In Northern Ireland.

Contemporary Social Science, 14.

https://doi.org/10.1080/21582041.2019.1585564?scroll=top\&needAccess=true

\section{Published in:}

Contemporary Social Science

\section{Document Version:}

Peer reviewed version

Queen's University Belfast - Research Portal:

Link to publication record in Queen's University Belfast Research Portal

\section{Publisher rights}

(C) 2019 Academy of Social Sciences. This work is made available online in accordance with the publisher's policies. Please refer to any applicable terms of use of the publisher.

\section{General rights}

Copyright for the publications made accessible via the Queen's University Belfast Research Portal is retained by the author(s) and / or other copyright owners and it is a condition of accessing these publications that users recognise and abide by the legal requirements associated with these rights.

Take down policy

The Research Portal is Queen's institutional repository that provides access to Queen's research output. Every effort has been made to ensure that content in the Research Portal does not infringe any person's rights, or applicable UK laws. If you discover content in the Research Portal that you believe breaches copyright or violates any law, please contact openaccess@qub.ac.uk. 


\title{
Sense making of Brexit for Economic Citizenship In Northern Ireland
}

\author{
Graham Brownlow (QUB) and Leslie Budd (Open) \\ Contemporary Social Science Summer 2019
}

Accepted $12^{\text {th }}$ October 2018

\section{Introduction}

Economic thought often wants to be separated from social and political thought. This separation, however, is difficult to carry through in a history of the idea of national and international economic integration, because social and political issues are inseparably linked with economic ones (Machlup, 1977: 70).

When models are selected judiciously, they are a source of illumination. When used dogmatically, they lead to hubris and errors in policy (Rodrik, 2015: 11). The economics profession had a less than stellar performance, in terms of communicating the economic consequences of Brexit, during the Referendum campaign on the United Kingdom's (UK) continuing membership of the European Union (EU). This communication failure followed the analytical failure a decade earlier to foresee the scale of the economic crisis (Johnson and Mitchell, 2017). Given the communication and analytical weaknesses it is unsurprising that the credibility of economics as a discipline has been under more sustained scrutiny, indeed attack, than at any time in recent intellectual history (Heath, 2016; John and Mitchell, 2017).

Economists, particularly since the 1950s, have built upon the foundations of international trade theory to erect a corpus of thinking about economic integration. ${ }^{1}$ The era of European economic integration, prior to 'the three' joining the Common Market, was underpinned by a well thought out theoretical literature, which in turn reflected the evolution of thinking about existing integration schemes (Meade, 1955; Scitovsky, 1958; Balassa, 1961; Streeten, 1961, Johnson, 1965). James Meade's work on Custom Unions is probably the best known and most influential product of this interaction between practice and theory.

This experience of European economic integration was until Brexit a one way process: hence the economic ramifications of Brexit, involving as it does impacts on product, labour and capital markets, is a clear example where while the existing 
conceptual toolbox offers useful insights (in the form of thinking about economic integration); it is equally the very complexity of the range of areas covered, and the unavoidable need for judgment, which means the economics of 'international disintegration' requires working out (Sampson, 2017). The mention of disintegration is particularly important: Brexit poses an analytical challenge as there is no well worked out theory of economic (dis)integration (Baldwin and Wyplosz, 2009; Begg, 2016; Moregnroth, 2017). For a general audience Brexit is a case of practice running ahead of theory. In such a situation "off the shelf" textbook solutions are not available.

The challenge for academics, policy makers and practitioners discussed in this paper is to analyse the composition, performance and trajectory of the Northern Ireland ( $\mathrm{NI})$ economy and identify the likely impacts of Brexit in the medium-term. Likewise, we focus on the large and dominant Agrifood sector that is more spatially distributed than other sectors, to discuss the potential consequences of Brexit. In addition, we examine how the border between the two parts of Ireland becomes a socio-economic beyond a physical one. In the remainder of this paper different conceptual tools are brought to bear in order to investigate these issues. In particular, concepts such as transaction costs and club goods are used to highlight aspects of Brexit. As the Kindleberger-Rodrik line of argument predicts, judgment is required in order to think about the appropriate models that need to be selected from the library in order to consider the ramifications of Brexit.

There are a number of models of Brexit that were set out at the time of the Referendum in 2016: World Trade Organisation (WTO); European Economic Area (EEA), as for Norway, inter alia; Customs Union, as for Turkey; Switzerland, sui generis; Comprehensive Economic and Trade Agreement (CETA) with Canada, as a recent example of an agreement with a non-European country (Emerson, 2016). At the time of writing, the imbroglio in the political negotiations within the UK and with the other EU27 Member seem to have reduced the choice of models to two; Exit the EU without agreement ('No Deal') or the proposed withdrawal agreement between the UK government and EU27 ('The May Deal'). All these possibilities cross-cut a number of constitutional, economic, political and social complexities but 
none provide a particular conceptualisation by which the scope and limits of these alternatives can be analysed.

A starting point for this research is to look at the different post-Brexit trade options that are on offer as a series of club goods that impact on sectors differently. Club goods are a form of collective goods that unlike public goods are non-rival in consumption but excludable. That is, one has to have club membership to access them, whilst non-members are excluded. As more people join the club the costs of membership decline but so does the enjoyment of the facility as congestion approaches. Total benefits of membership will decline at some point as congestion sets in. Thus, there is an optimal size where the cost of access equals the cost of restricting membership (Buchanan, 1965).

This is a novel approach for examining the impact of the various options, particularly trade in goods and services on offer, following Brexit. Given, the initially misunderstood role of Northern Ireland within the process, treating future relationships between $\mathrm{NI}$, Great Britain, the Republic of Ireland (ROI) and the rest of the EU as different club goods can make a contribution to the understanding of 'Beyond Brexit'. In the context of describing the club goods on offer to Northern Ireland, the key Agrifood sector is investigated in order to exemplify arguments about economic citizenship beyond Brexit. As argued below the Agri-food sector's importance to the NI economy goes beyond is nominal size in that it is not only a large employer but it is part of a key Global Value Chain (GVC) within an All-Ireland market that's cuts across other EU markets Including those in Great Britain. Its historical and cultural significance also form part of the components of the contribution of this sector to economic citizenship.

The strong links between trade and FDI are also crucial with respect to not only cross-border co-operation ${ }^{2}$ but also the strategic direction of economic policy in both parts of Ireland. In particular, the harmonisation of Corporation Tax (CT) from April 2018, as a central discourse of attracting FDI in key sectors, may now be redundant depending upon which Brexit club good will be offered. The essential issue is how the different trade options will impact upon the key sectors that the Northern Ireland Economic Strategy and 
the Programme for Government identifies as the 'Matrix' sectors, including the Agri-Food (Northern Ireland Executive, 2012).

\section{Transaction Costs, Brexit and the Northern Ireland Economy}

The mainstream of the UK economics profession was unconvinced that Brexit would produce economic net benefits (Johnson and Mitchell, 2017; Sampson, 2017). Among the minority of economists advocating Brexit during the referendum campaign, it was argued that exiting the EU would reverse "red tape"; this would promote deregulation allowing for lower transaction costs ${ }^{3}$ and improved economic performance (Economists for Brexit, 2016). In reality, the opposite has been the case: the processes associated with Brexit have generated significant transaction costs not only for the UK but also its EU partners (Chen, Los, McCann, Ortega-Argiles, Thissen, van Oort, 2018). The negotiations between the UK government and the European Commission (EC) at the time of writing, notwithstanding, 750 treaty obligations, 12000 product regulations and 6250 World Trade Organisation (WTO) tariff lines (depending upon the deal for fisheries and agriculture) need to be re-negotiated, are just the initial amount of transactions costs. ${ }^{4}$ For this to be undertaken within a two-year period since the triggering of Article 50 of the Lisbon Treaty in March 2017. The more profound implications for Brexit are the potential break-up of the United Kingdom, as the Sewell Convention did not provide the right of the devolved nations to veto the contents of negotiations over of Brexit. ${ }^{5}$ Yet addressing the economic and spatial imbalances in the UK are central to addressing the impact of Brexit after the UK leaves the EU.

Brexit appears to be treated as a mono-causal event in some accounts in which the process of leaving should be straightforward enough, given political will and authority (Economists for Brexit, 2016). By the same token, the Leave Vote result is seen by some as merely as a factor of xenophobia combined with the dissatisfaction of people and places left behind by the EU's globalizing modernity. The EU may have crystalized as the emblem of the status quo of out-of-touch political elites who imposed lower real wages and worse socio-economic welfare through austerity. The apparently plausible reasons for voting to leave, however, have their roots in extra-EU factors ${ }^{6}$ (Dorling, 2016, Evans 
and Menon, 2017; Los, McCann, Springford, and Thissen, 2017; Bailey and Budd, 2017, Hill, 2018).

A first way in which we need to think about the appropriate tools needed to investigate the economic impact on Brexit within Irish Agrifood is to recognise the complexity of the Northern Irish context. Discussions of the Northern Irish economy often assume that the problem is merely that it suffers from an excessive dependence on the public sector and the cure is rebalancing (HM Treasury, 2011, Centre for Economic Empowerment, 2014; MacFlynn, 2016a, Brownlow and Birnie, 2018). Yet this diagnosis is unhelpful in thinking about the post-Brexit economic landscape. In essence, NI's economy faces three different categories of economic problem, none of which can be plausibly reduced solely to the relative size of the public sector (Brownlow and Birnie, 2018). ${ }^{7}$

1. The weaknesses it shares with the UK as a whole. Macroeconomic policy failure can be placed in this category (Crafts, 2012).

2. Magnified versions of UK-wide deficiencies. Supply-side weaknesses in the areas of training, management quality and innovation can be placed in this category Bloom and van Reenan, 2010).

3. Problems unique to the regional economy. It is important to note that the economic challenges are not entirely region-specific; instead they relate to unbalanced spatial and structural economics that has been allowed to emerge in the UK in the decades prior to Brexit (Pike et al, 2012; Tomlinson, 2014). Delving deeper, $\mathrm{Nl}$ as an economy also suffers from a magnified version of the UK's productivity woes. Gross Value Added (GVA) per head in NI has never reached the UK average and the gap has not narrowed, despite the UK-wide productivity slowdown of recent years. In 2005, GVA per capita was $80.6 \%$ of the UK average, by 2015 that had declined to $73.8 \%$. Other measures show a persistent gap of $20 \%$ and $25 \%$ between $\mathrm{NI}$ and the UK average and persistent gap between $\mathrm{NI}$ and other UK regions (Mac Flynn, 2017). Low investment, wages and skills are interconnected sources of both UK and NI productivity woes. Furthermore, the structure of NI, with a greater dependency on public 
spending and agriculture than the rest of the UK, has dangers of magnification. This is also compounded by the size structure of $\mathrm{NI}$ firms that are more frequently family-owned and less productive than the rest of the UK (Brownlow, 2017). ${ }^{8}$

The current uncertainty about the economic impact of Brexit, has led to increased direct and transaction costs, as exchange depreciation has increased imported food, energy and travel costs. The conventional J-curve effect on exports that arise from a depreciated currency have so far not manifested itself ${ }^{9}$. Partly, this is due that in regard to UK-rest of EU trade $60 \%$ of which is accounted for by intra-firm transactions so that more cheaper UK exports of parts etc, have not compensated for more expensive EU imports (EUROSTAT, 2017; Bailey and de Propris, 2017a; 2017b). Given that modern trade functions mainly through regionally distributed Global Production Networks (GPNs), it is reasonable to doubt that any $\mathrm{J}$-curve benefits will be sustained in the medium term (Dicken 2014; Baldwin, 2016; Yeung, 2017).

We can go further and suggest that the existing damage to the UK economy may be exacerbated by the current negotiating stance by the May government ; one that may have to change due to force majeure (Evans and Anand, 2017) Given that no respectable economist has suggested that the Brexit Referendum result would immediately damage the UK economy, the consensus on the medium to long term effects are likely to increase the impact of these outcomes (Crafts, 2016; Ebel and Warren, 2016; H.M. Treasury, 2016: Oxford Economics, 2016; PWC 2016; Portes and Forte, 2016; Springford, Tilford, McCann, Whyte and Odendahl, 2016; Erken et al, 2017; Clarke, Serwicka and Winters, 2017; Cambridge Econometrics, 2018). The range of the loss of national income for the UK up to 2030 is between $3 \%$ and $6 \%$, from which an be a figure of $3 \%$ loss for the direct impact on Northern Ireland can be imputed, that has now risen since the original estimates (Budd, 2015; Budd, 2017; Cave and Allen, 2016; Fitzgerald and Hohohan, 2016; MacFlynn, 2016b; Oxford Economics, 2016; Stennett, 2016). The UK government's own study of the impact of suggested that the loss of national income from the various possible post-Brexit trade deals could be between $2.5 \%$ for just remaining in Single European Market (SEM); 8\% for a Free Trade Agreement; 
and, $12 \%$ for No Deal (House of Commons Exiting the European Union Committee, 2018). Consequently, $\mathrm{NI}$ is likely to suffer the biggest impact from Brexit that would also undermine the scale and scope of cross-border co-operation and economic flows in what is a de facto an All-Ireland Single Market. The three trade options can be viewed as club goods, whose detailed analysis with respect to $\mathrm{NI}$ is analysed below.

This analysis rests upon an assumption that the present UK's stance on Brexit has become path-dependent. It would need a major positive shock to reverse this dependency that even a decision to delay or reverse Article 50 may have limited impact. That shock may be the return of above trend growth in the rest of the $\mathrm{EU}$, that sustains demand in the UK economy in the short to medium term, although given the potential cleavages in the Eurozone, this is uncertain.

Managing the process of the UK exiting from the EU is one of the most difficult issues for public policy in post-war history. In the case of $\mathrm{NI}$, it is the most complex and challenging one of all the UK territories. Its current benefits include an all-Ireland single market; the second largest market for NI trade; close cross-border FDI and economic cooperation and flows; and, a common travel area. If the $\mathrm{NI}$ economy is not to be damaged and its economic citizenship undermined permanently, a bespoke Brexit agreement may be an imperative. That agreement would also have to be based upon an all-Ireland constitutional solution; itself a profound challenge for resolving the issues of the Single Market and customs union in regard to the internal Irish border (Murphy, 2018).

\section{Misunderstanding of the role of modern trade in the Global Economy}

Moving from Brexit and the faultlines within the $\mathrm{NI}$ economy to the economics of trade and investment, the implications of economic communication again appear as an issue. Likewise, the importance of a few key concepts are also key in establishing clear thinking about the probable economic consequences of Brexit for $\mathrm{NI}$ and the Agrifood sector in particular. The EU Referendum and US Election demonstrated ignorance by politicians and commentators (on all sides) and about modern economies and trade underpinned by unchallenged communication to the public. Economic globalisation was first driven by trade is followed by FDI (OECD, 2008). FDI enables GPNs and thus Global 
Value Chains (GVCs) with supply chains (GSCs) providing the link between GPNs and GVCs (Yeung, 2017). The latter are drivers of global trade as demonstrated by the large proportion of EU trade being intra-firm. Supply chains go back centuries, which today are variants of commodity chains. A commodity chain is: "a network of labour and production processes whose end result is a finished commodity" (Hopkins and Wallerstein, 1986;158). ${ }^{10}$

GPNs are the globally organized networks of interconnected functions and operations of firms and non-firm institutions through which goods and services are produced, distributed, and consumed. A key concern of GPN analysis is to explore how the nature of these complex networks affects processes of economic development in the various territories that they interconnect. (Coe, 2009; 556). In promoting cross-border trade, within firms and between them and consumers, supply chains create the opportunity for the GVCs to be realised that are now the major driver of economic activities across national borders. GPNs link FDI to GVCs and international trade that is increasingly intra-firm. Consequently, as distance doubles trade halves thereby creating incentives for the development of Regional Trade Areas (RTAS), for example the EU (Armstrong, 2017).

In the case of Northern Ireland, its largest twenty companies are foreign-owned that are also are part of GPNs and GVCs underpinned by supply chains, covering a number of key sectors (Northern Ireland Executive, 2012, Department for Economy, Northern Ireland, 2016). In the Northern Ireland Executive's economic strategies, the key growth sectors are termed MATRIX that include:

- $\quad$ Telecommunications \& ICT;

- $\quad$ Life \& Health Sciences;

- $\quad$ Agri-food;

- $\quad$ Advanced Materials;

- $\quad$ Advanced Engineering.

These sectors are most exposed to FDI; a driver of domestic productivity along with cross-national intra-firm trade (Donnolly, 2014). These sectors, however, cannot 
compensate for the relatively poor productivity performance of the $\mathrm{NI}$ economy. The majority of employment is in the low productivity sectors of agriculture, construction and retail (ONS, 2017) In the case of ICT, a key MATRIX sector, it was one of three sectors in NI whose productivity performance was worst in all UK regions in 2017. (OECD, 2017). The prioritisation of the MATRIX sectors is reflected across the border in the economic and industrial strategies in the Republic of Ireland (ROI), thereby reinforcing the rationale of cross-border collaboration in what is effectively an all-Ireland single market (Northern Ireland Assembly, 2016). A snapshot of collaboration this is given in Table 1 below:

Insert Table 1 here

As a result, there is a high degree of cross-border flows and co-operation. In the case of the Agrifood sector the importance of cross-border trade is shown in Table 2 below. This does not include food processing, the other part of the Agrifood sector, partly because the cross-border flows are intra-firm as part of GVCs within this sector.

The importance of cross-border GVCs can also be seen in other MATRIX sectors, for example aerospace. ${ }^{11} \mathrm{~A}$ similar threat, that may be more damaging in the medium to longer term, is apparent for the Agrifood sector. Consequently, Brexit represents a significant challenge to two of the leading MATRIX sectors with spillover effects into

Table 2 here

others. The role of Agrifood extends beyond a straightforward economic calculus to include its centrality to culture and identity in essentially all-Ireland rural society (Doyle, 2019). There is also an environmental significance, in that Irish agriculture is in the forefront of sustainability (Cahill, 2010). This equally applies to fisheries in which leading research co-operation is a consistent feature of the rural economy (Northern Ireland Assembly, 2011). The cultural dimension feeds into associated economic activities, for example leisure and tourism and related business and financial services. It follows that an argument can be made of the significance of Agrifood for creating economic 
citizenship in the island of Ireland. These cross-border spillover effects and those of trade disintegration are not part of the conventional calculus of the costs of Brexit but for $\mathrm{NI}$ and the ROI they are crucial,

\section{Can the complexities of Brexit be made sense of for Northern Ireland?}

$\mathrm{NI}$ as a regional polity and economy, while sharing with other western and northern regions in the spatial economic problems, is unique in two respects. Firstly, it is the only part of the UK with a contiguous border with another EU Member State that is also a member of the Eurozone. Secondly, following the Good Friday Agreement (GFA) of 1998, that marked the end of internecine conflict, a power sharing agreement between the major political parties has been in place. Given this complexity a bespoke Brexit agreement may be an imperative if the $\mathrm{NI}$ economy is not to be damaged over the medium to longer term. The attendant consequences for economic citizenship and governance possibly being undermined permanently are central to this analysis.

To date, there has been little academic published work on the direct impact of Brexit on the $\mathrm{NI}$ economy. Most of the analysis attempts to decompose the UK impacts to the appropriate territorial scale. Table 3 gives an overview of the relative performance of the UK and $\mathrm{NI}$ economies in respect of forecasts before and adjusted for Brexit. The relative fragility of the $\mathrm{NI}$ economy, as discussed in previous sections, is readily apparent in this table.

Table 3 here

In 2015, the Agrifood sector accounted for $3 \frac{1}{2} \%$ of GVA and $5.5 \%$ of Northern Irish employment. In the ROI it accounted for $7.8 \%$ of GVA and $8.6 \%$ of employment in the same year. There is a high degree of cross-border co-operation that create significant spillovers in terms of demand for machinery, business and financial services, as well as research and development and establishing best practice in sustainability (Environment Protection Agency, 2014). Consequently, the impact of Brexit on this sector will be 
significant, especially in two essentially rural economies and for whom the border between them is fundamentally irrelevant.

The potential damage to this key sector from Brexit has profound implications for economic citizenship but also forms of economic governance, for example industrial strategy and policy, to which the 'Matrix' sectors are central. But it is indirectly related to citizens' expectations about Brexit outcomes with respect to how economic citizenship may change in NI viz a viz ROI and Great Britain. The subsequent governance issues are complex and challenging, whose political ramifications may be very arduous and the outcome ultimately unwelcome but necessary. Making sense of Brexit for $\mathrm{NI}$, as well as the ROI, can only start with the explicit recognition by all parties that $\mathrm{NI}$ with respect to the Island of Ireland, the UK and the EU is a special case. Failure to understand this apparent fact is likely to damage economic citizenship and weaken related governance over the longer term

\section{Towards Economic Citizenship}

Economic citizenship can be investigated by considering analytical tools. We can apply Musgrave and Musgrave's famous economic analysis of the functions of government in order to explicate the notion of economic citizenship (Musgrave and Musgrave, 1973). They argued that the three functions (allocation, distribution and stabilisation) were required by governments to manage the economy. Allocation would rectify market failures via the provision of social goods. Distribution would seek to rectify inequality through the fiscal system and the provision of merit goods and stabilisation relates to macroeconomic policy (Musgrave and Musgrave, 1973).

These three functions also provide the conditions for defining economic citizenship as the inclusion of citizens in the allocation, distribution and stabilisation of resources to enhance their socio-economic welfare and well-being in the territories they inhabit and shape. The Agrifood sector is emblematic and crucial in assessing and investigating in detail the consequences of Brexit. This is a given because of its significant position in respect of trade and FDI in the island of Ireland; income and employment; spillovers into other economic sectors, and, its key position in balancing 
socio-economic welfare between the rural and urban economy in NI (Donnelly, 2014). Moreover, the supply chains underpinning the GVCs in this sector challenge any utility of re-asserting a physical border between the two parts of Ireland. In short, the economic consequences of Brexit are potentially even more complex in the $\mathrm{NI}$ case because it shares weaknesses with the UK, magnified versions of UK problems and as well as those unique to the region.

This complexity is increased in respect of some of the conditions of the GFA, guaranteed certain equality rights to all citizens in the island of Ireland, that are not enjoyed in the rest of the UK (O'Connell and Harvey, 2017). These rights have socioeconomic implications that contribute further to economic citizenship. In this regard, demand for a special case of Ireland framed by the GFA is strengthened by the potential impact of Brexit on this form of citizenship. In this context, Brexit represents a governance challenge that is exacerbated by the uncertainties covering what form it will eventually take. The governance environment in any economy is crucial to realising the benefits of economic citizenship. In the case of the whole of the UK, the different arrangements that may result from Brexit can be characterised as club goods, access to which is a crucial component of economic citizenship. Table 4 below shows the different club goods that may result from Brexit, as they impact upon the Agrifood sector, with a column setting out the levels of degree of transaction costs for each option.

\section{Agrifood as driver of Economic Citizenship in Ireland}

The Agrifood sector is an important part of both economies of Ireland that also has significant cultural and political aspects; details of which are set out above. It follows that in reviewing its role of creating and sustaining economic citizenship, these aspects are very important. As one of the key MATRIX sectors, it is quite central to the formulation of industrial strategy and policy, as well as to cross-border co-operation and trade in respect of:

1. High degree of integration in cross-border trade links: $10 \%$ to $12 \%$ of the ROl's exports to the UK go to $\mathrm{NI}$, and $7-8 \%$ of imports. As $\mathrm{NI}$ makes up for only $3 \%$ of UK population, these figures show the strong economic inter-connectedness 
of both parts of Ireland. Other work by InterTrade Ireland $(2009,2011)$ suggests that the level of trade integration has greater potential.

2. Supply chains are a major factor in cross-border trade: Trade in intermediate goods is a large element in cross-border trade. Furthermore, a significant share is accounted by simultaneous trade in both directions. In the InterTrade Ireland study, Cross-Border Trade and Supply Chain Linkages Report, these two-way traders make up around 18 per cent of firms of its study sample but accounted for over 60 percent of exports and over 70 per cent of imports $\square$ in 2015 . The share of intermediates in imports from Northern Ireland to Ireland is higher in almost all sectors than trade in the same sectors from the rest of the UK. Using more detailed firm level data shows that a majority of cross border trade occurs in intermediate inputs and highlights the considerable level of interconnectedness of cross-border supply chains.

3. Cross-border traders evidence of flexibility and innovation: There is a high level of ongoing product turnover amongst trading firms with a regular introduction of new products and innovation. This pattern is consistent across firm size, categories and between food and non-food firms. As a result there is a high level of potential dynamism and amongst cross- border traders. In a post- Brexit environment these characteristics will be crucial in dealing with cross -border challenges. (intertrade Ireland, 2018). 
In regard to the Agrifood sector, the following case exemplifies the importance of its GVCs and supply chains that underpins cross-border co-operation and trade. It is

\section{LacPatrick Cross Border Dairy Case Study}

Milk tankers cross the border between Ireland and Northern Ireland about 33,000 times a year. Northern Ireland produces around 2.2 billion litres of milk a year, of which $30 \%$ is processed in the Republic.

Milk and dairy products move in both directions, sometimes several times: cream from Northern Irish milk is removed in Virginia, Co.Cavan, Ireland and sent back to the Baileys Irish Cream plant in Mallusk, Co. Antrim, Northern Ireland.

This complex cross-border supply chain, which is heavily dependent on Irish exports of milk powder and baby formula to markets in West Africa, the Caribbean and Asia, is exposed on two fronts.

First, in the event of a hard Brexit, the north-south milk trade would become unprofitable due to tariffs ranging from $40 \%$ to as much as $64 \%$ depending on fat content. LacPatrick in Monaghan for example currently $\square$ takes about 100 million litres from a cooperative in Ballyrashane (Co. Antrim) with which it merged in $\square 2015$. The introduction of tariffs could make LacPatrick change its processing operations, possibly by processing milk from Northern Ireland within Northern Ireland. Ireland -the company has recently invested in its $\square$ plant in Artigarvan, Co. Tyrone, Northern Ireland, where investment of $€ 45 \mathrm{~m}$ has provided the capacity to spraydry 2.5 million litres a day.

Second, is the fact that milk powder is exported under EU export agreements. When the UK exits the EU it will no longer be included with the EU export agreement with China (the main destination of LacPatrick powdered milk), and it could take a period of years to put new export agreements in place in key milk powder markets. (InterTrade Ireland, 2018)

apparent that these characteristics, particularly the last, are important in challenging and changing the path dependent nature of the $\mathrm{NI}$ economy, industrial strategy and policy. In the event of Brexit, these opportunities will be lost.

In regard to the NI Executive's consultative document on industrial strategy, Europe2030, there is little analysis or mention of the role of the Agrifood sector except that it is one of six key sectors in "going for growth" (Department for the Economy, 2017). The document refers to the Agri-Food Strategy Board 2013 study Going for Growth, a Strategic Plan for the sector with targets for growing turnover by $60 \%$ to $£ 7$ billion by 
2020 (Agri-Food Strategy Board, 2013). Turnover had increased by $23 \%$ to $£ 4.6$ billion in 2015 , with employment in the food and drink processing industry increasing by $8 \%$ from 2010 to 23,500 in 2015. In the light of the uncertainty created by Brexit, the targets set by the Plan are unlikely to be met. Moreover, the lack of any analysis or mention of the parametric constraint of Brexit Economy2030 is surprising to say the least. Furthermore, the strategy does not address the key problem of path dependency in the $\mathrm{NI}$ economy and its supporting policy framework. Perhaps more surprisingly is the lack of any analysis of thye role Agrifood in cross-border co-operation and trade: a sector that may derail the whole Brexit process if the border issue is not solved to the advantage of the whole of Ireland and its single market.

At the time of writing the Irish border question has become the keystone for building a satisfactory negotiation over Brexit. To date expert analysis has shown that many of the proposals emanating from the UK government are neither feasible nor realistic (Hayward, 2018a, 2018b). The role of Agrifood and its GVCs is crucial in what is an all-Ireland single market. Moreover, this sector and its sustainability is central to economic citizenship so that a 'hard border' outcome of Brexit will be detrimental to local economies on both sides of the border, particularly in Northern Ireland where economic activity is greater compared to the ROl's border region.

\section{Concluding Comments}

The introduction to this paper argued that economists' thinking about Brexit needs to recognise the limitations of "off the shelf" models. Such a viewpoint places this paper close to Kindleberger's (1989) or Rodrik's (2015) argument which states that we should be sceptical about universal models explaining every economic issue. Rodrik's analysis implies that we need to exercise judgment in terms of choosing between models. In terms of the tools used to examine Brexit we have seen that club goods, transaction costs and supply chain models are all useful for studying aspects of the issue. This emphasis on judgment echoes Keynes famous dentist metaphor, but it suggests we go further and not restrict ourselves to one drill or pair of pliers if we want to provide as painless an extraction as possible (Kindleberger, 1989). 
It is in this context that we attempt to make sense of the most challenging economic territory for Brexit. That territory is Northern Ireland that although is a devolved nation within United Kingdom, it effectively exists in an all-Ireland single market, due to its special constitutional position and geography. This position rests on the Common Travel Area (CTA) of 1923 and the Good Friday Agreement (GFA) of 1998. The latter is especially pertinent is that it is underwritten by the UK and US governments and the EU and bestows socio-economic rights to the citizens of Northern Ireland that are not available to the rest of the UK. These constitutional and institutional arrangements underpin cross-border co-operation and economic flows. Bordering another EU Member State reinforces the role of GVCs in a number of key sectors in both parts of Ireland and thus sustaining economic citizenship. The socio-economic and cultural importance of the Agrifood in the whole of Ireland makes it a very useful case study in exploring the complexity of the $\mathrm{NI}$ economy and challenges to economic citizenship that arise from Brexit. A useful heuristic device is to apply the theory of club goods to the different trade options that may be implemented after Brexit with respect to the role of Agrifood. In doing so, it opens up a means of exploring changes in economic citizenship as a result of the implementation of each of these options. In this regard, the point of congestion for the particular Brexit club good on offer is an important consideration in that market access for producers and consumers may be limited due to its smaller size compared to current EU membership.Foll owing on from this paper, we hope to contribute to new research programmes and in debates beyond Brexit that attempt to make sense of the greatest challenge to the economy and polity of the UK and its neighbours in the post-war period.

\section{References}

Agri-Food Strategy Board (2013) Going for Growth: A Strategic Action Plan in support of the Northern Ireland Agri-Food Industry, Belfast; Agri-Food Strategy Board.

An Phríomh-Oifig Staidrimh (CSO) (2017) Regional economics Trends, Dublin: An Phríomh-Oifig Staidrimh/ Central Statistics Office.

Armstrong, A. (2017) No Free Lunch for Global Britain NIESR Blog, January, London: National Institute for Economic and Social Research

Bailey, D. and de Propris, L (2017a) What does Brexit mean for UK automotive and In industrial policy D.Bailey and L.Budd (eds) The Political Economy of Brexit, Newcastle; Agenda Publishing. 
Bailey, D., \& De Propris, L. (2017b).Brexit and the UK Automotive Industry. National Institute Economic Review, 242(1), R51-R59.

Bailey, D. and Budd, L. (2017) Introduction: the political economy of Brexit, in D.Bailey and L.Budd The Political Economy of Brexit, Newcastle: Agenda Publishing.

Balassa, B. (1961) Towards a Theory of Economic Integration Kyklos, 14 (1), 1-17.

Baldwin, R. and Wyplosz C. (2009) Economics of European Integration (3 ${ }^{\text {rd }}$ ed.), Columbus OH; McGraw-Hill Education

Baldwin, R (2016) The Great Convergence: Information Technology and the Globalization, London; The Bellnap Press of Harvard University Press.

Begg, I. (2016) Brexit: why, what next and how? CESifo Forum, 17 (1), 30-36,

Belfast Telegraph (2017) US tariff decision 'could see Bombardier question the economics of staying here' 28 September,

Bloom, N. and Van Reenam, J. (2010) Why Do Management Practices Differ across Firms and Countries? Journal of Economic Perspectives, 24 (1), 203-24.

Brownlow, G. (2017) Practice Running Ahead of Theory? Political Economy and the Economic Lessons of UK Devolution Cambridge Journal of Regions, Economy and Society. 10 (3) 559-573.

Brownlow, G and Birnie, E. (2018) Rebalancing and Regional Economic Performance: Northern Ireland in A Nordic Mirror Economic Affairs, 38 (1), 58-73.

Buchanan, J.M. (1965) An Economic Theory of Clubs, Economica, 32 (125), 1-14.

Budd, L. (2015) The Consequences for the Northern Ireland Economic if The United Kingdom Exits form the European Unions, Committee for Enterprise, Trade and Investment (CETI) Briefing Note 03/15, Belfast; Northern Ireland assembly.

Budd, L. (2016) Economic Challenges and Opportunities of Devolved taxation in D.Bailey and L.Budd (eds) Devloution and the UK Economy, London; Rowan \& Littlefield.

Budd, L. (2017) Stalling or Breaking? Northern Ireland's Economy in the Balance in D.Bailey and L.Budd The Political Economy of Brexit, Newcastle: Agenda Publishing.

Cahill, N. (2010) The Impact of European Environmental Policy in Ireland, National Economic \& Social Council Background paper 5. Dublin; National Economic \& Social Council.

Cambridge Econometrics (2018) Preparing for Brexit, Cambridge: Cambridge Econometrics.

Cave, S. and Allen, M. (2016) Possible models for the UK-EU relationship post 'Brexit' Research and Information Service Briefing Paper 47/16, Belfast, Northern Ireland Assembly.

Centre for Cross Border Studies (2017) A study of cross-border flows within the agri-food sector:: A snapshot of four border counties, Armagh: Centre for Cross Border Studies 
Centre for Economic Empowerment (2014) Economic Attitudes in Northern Ireland, Belfast; Northern Ireland Council for Voluntary Action (NICVA).

Chang, H-J (2014) Economics: The User's Guide, London; Penguin Books.

Chen, W., Los, B., McCann, P., Ortega-Argiles, R., Thissen, M., van Oort, F (2018) The Continental Divide? Economic Exposure to Brexit in Regions and Countries on both sides of the Channel, Papers in Regional Science, 97(1), 25-54.

Clarke, S.. Serwicka, I, and. Winters, L.A. (2017) Will Brexit raise the cost of living? National Economic and Social Research Review, 242, (1), R37-R50.

Coe, N.M (2008) Global Production Networks International Encyclopedia of Human Geography, 556-562

Crafts, N. F. R. (2012) British relative economic decline revisited : the role of competition. Explorations in Economic History, 49(1), pp. 17-29

Crafts, N. (2016) Brexit: Lessons form history, in R.E.Baldwin (ed) Brexit beckons: thinking ahead by leading economists, A Voeux e-book, London: CEPR Press.

Department for Economy, Northern Ireland, (2017), Economic Commentary, March, Belfast; Northern Ireland Executive.

Dicken, P. (2014). 'Global Shift: Mapping the Changing Contours of the World Economy. (7th edn.) London; Sage.

Donnolly, D. (2014) A Review of the Literature Regarding the Determinants of Foreign Direct Investment (FDI) Research and Information Service Briefing Paper NIAR 86214, Belfast; Northern Ireland Assembly.

Dorling, D. (2016) Brexit; The Decision of a Divided Country, British Medical Journal, 354: i3965.

Doyle, P. (2019) Civilising rural Ireland: The co-operative movement, development and the nation-state, 1889-1939, Manchester; Manchester University Press (forthcoming).

Ebel, M. and Warren, J. (2016) The long term impact of leaving the EU, National Institute Review of Economic and Social Research, 236, 121-138.

Economists for Brexit (2016) The Economy after Brexit, London; Economists for Brexit.

Environment Protection Agency (2014) Sustainability Strategy 2014-20, Dublin; EPA.

Erken, H. Hayat, R. Prins, C. Heijmerikx, M. de Vreede, I. Measuring the permanent costs of Brexit National Institute Economic Review, 244

EUROSTAT (2017) Intra-EU trade in goods - recent trends, Luxembourg; EUROSTAT.

Evans, G. and Menon, A. (2017) Brexit and British Politics, Cambridge: Polity Press.

Farming Life (2017) £362,635 for new agri-food research projects, 12 August, Farming Life: Portadown.

Fitzgerald and Hohohan, (2016) Ireland and Brexit, in R.E.Baldwin, Brexit beckons: thinking ahead by leading economists, A Voeux e-book, London: CEPR Press. 
Gallagher, J. (2017) A Scottish perspective; charting a path through the rubble in policy D.Bailey and L.Budd (eds) The Political Economy of Brexit, Newcastle; Agenda Publishing.

Gereffi, G. Korzenwiecz, M. and Korzeniewicz, R.P. (1004) Introduction: Global Commodity Chains in G. Gereffi, M. Korzenwiecz, and R.P. Korzeniewicz, (eds) Commodity Chain and Global Capitalism, 1-14, Westport, CT; Praeger Publsihers.

Hayward, K. (2018a) Last Word: Brexit's Border Problems Political Insight (2018) 9 (2)., 40.

Hayward, K. (2018b) Can technology and 'max fac' solve the Irish border question? Expert explains, The Conversation, 23 May.

Heath, A. (2016) Economists have a century of failure behind them. No wonder they back Remain now Daily Telegraph 18 May.

Hill, C. (2018) Turning back the clock: The illusion of a global political role for Britain in B. Martill, B and U. Staiger, (eds) Brexit and Beyond: Rethinking the Futures of Europe, London; University College Press

H.M. Treasury (2011) Rebalancing the Northern Ireland economy, London; H.M. Treasury.

HM Treasury (2016) The long-term impact of EU membership and the alternatives, April, London; H.M.Treasury.

Hopkins, T. and Wallerstein, I. (1986) Commodity chains in the world economy prior to 1800. Review X (1) 157-170.

House of Commons Exiting the European Union Committee (2018) EU Exit Analysis Cross Whitehall Briefing, Westminster; UK Parliament.

HRMC (2017) Regional Trade Statistics, London; Her Majesty's Revenue and Customs.

Intertrade Ireland (2009) Regulatory Barriers to Cross-Border Trade and Business, Newry: InterTrade Ireland

Intertrade Ireland (2011) Agri-Food: A Study for Cross-Border Cooperation, Newry; InterTrade Ireland.

InterTrade Ireland (2018) Cross-Border Trade and Supply Chain Linkages Report, Newry: InterTrade Ireland.

Johnson, H. (1965) An Economic Theory of Protection, Tariff Bargaining and the Formation of Customs Unions Journal of Political Economy, 73, 256-283.

Johnson, P. and Mitchell, I (2017) The Brexit vote, economics, and economic policy, Oxford Review of Economic Policy, 1,IS1, S12-S21

Joint Committee on Jobs, Enterprise and Innovation (2016) Report on All-Island, Dublin: Economy, Houses of the Oireachtas.

Kindleberger, C. (1989) Manias, Panics, and Crashes: A History of Financial Crises, New York; Basic Books.

Los, B. McCann, P. Springford, J. and Thissen, M. (2017). The mismatch between local 
voting and the local economic consequences of Brexit. Regional Studies, 51(5) 786799.

Maclup, F (1970) Homo Oeconomicus and His Class Mates, in M. Natanson, (ed), Phenomenology and Social Reality: Essays in Memory of Alfred Schutz, 122-139 London, Springer Nature.

McCrudden, C. (2017) The Good Friday Agreement, Brexit, and Rights A Royal Irish Academy - British Academy Brexit Policy Discussion Paper, Dublin and London; Royal Irish Academy and British Academy.

MacFlynn, P. (2016a) Productivity and the Northern Ireland Economic NERI Working Paper NERI WP 2016/No 39, Belfast; Nevin Economic Research Institute.

MacFlynn, P. (2016b) The economic consequences of BREXIT for Northern Ireland, NERI Working Paper NERI WP 2016/No 35 Belfast; Nevin Economic Research Institute.

MacFlynn, P. (2017) Industrial Policy in Northern Ireland: A Regional Approach, NERI Woking Paper WP2017/No 42, Belfast; Nevin Economic Research Institute.

Maclup, F (1970) Homo Oeconomicus and His Class Mates, in M. Natanson, (ed), Phenomenology and Social Reality: Essays in Memory of Alfred Schutz, 122-139 London, Springer Nature.

McCrudden, C. (2017) The Good Friday Agreement, Brexit, and Rights A Royal Irish Academy - British Academy Brexit Policy Discussion Paper, Dublin and London; Royal Irish Academy and British Academy.

Meade, J E. (1955) The Theory of Customs Unions. Amsterdam: North-Holland.

Morgenroth, E. (2017) Examining consequences for grade; integration and disintegration Effects in D.Bailey and L. Budd (eds) The Political Economy of Brexit Newcastle; Agenda Publishing.

Murphy, M.C. (2018) Europe and Northern Ireland's Future: Negotiating Brexit's Unique Case, Newcastle; Agenda Publishing.

Musgrave, R.A. and Musgrave, P.B. (1973) Public Finance in Theory and Practice, New York; McGraw-Hill.

Nauwelaers, C., K. Maguire and G. Ajmone Marsan (2013), The Case of the Top Technology Region/Eindhoven-Leuven-Aachen Triangle (TTR-ELAt) - Regions and Innovation:Collaborating Across Borders", OECD Regional Development Working Papers 2013/22, Paris; OECD Publishing.

Northern Ireland Assembly (2011) The Sea Fishing industry in Northern Ireland -issues, challenges and opportunities Research and Library Service Briefing Paper, 33/11, Belfast; Northern Ireland Assembly

Northern Ireland Assembly (2016)

Northern Ireland Executive (2012) Economic Strategy: Priorities for sustainable growth and prosperity: building a better future, Belfast; Northern Ireland Executive

O'Connell, R. and Harvey C. (2017) Brexit and Northern Ireland: The Constitutional, 
Conflict Transformation, Human Rights and Equality Consequences, Knowledge

Exchange Seminar Series (KESS) 25 October, Belfast; Northern Ireland

Assembly.

OECD (2008) OECD Benchmark Definition of Foreign Direct Investment - 4th Edition, Paris; Organisation for Economic Co-operation and Development.

OECD (2017), United Kingdom: Country Review, October, Paris; Organisation for Economic Co-Operation and Development.

ONS (2017) Regional Trends, London; Office for National Statistics.

Oxford Economic (2016 ) Assessing the economic implications of Brexit, Oxford; Oxford Economics

Özveren, E. (1994) The Shipbuilding Commodity Chain, 1590 - 1790 in G. Gereffi, M. Korzenwiecz, and R.P. Korzeniewicz, (eds) Commodity Chain and Global Capitalism, 17 - 19, Westport, CT; Praeger Publsihers.

Pike, A. Rodriguez, A. Tomaney, J. Torrisi, G. and Tseolis, V. (2012) In Search of the 'Economic Dividend' of Devolution: Spatial Disparities, Spatial Economic Policy, and Decentralisation in the UK, Environment and Planning C: Politics and Space, 30 (1), 10-28.

Portes, J. and Forte, G (2016) The economic impact of Brexit: Immigration, Oxford Review of Economic Policy, 33, (IS1,1), SS 31-44.

PWC (2016) Leaving the EU: Implications for the UK economy', March. London; Price Waterhouse Coopers.

PWC (2017) Northern Ireland Economic Outlook: What comes next?...Belfast; Price Waterhouse Coopers

Rodrik, D. (2015) Economics Rules: The Rights and Wrongs of the Dismal Science London: W.W. Norton \& Co.

Rubinstein, A. (2017) Comments on Economic Models, Economics, and Economists: Remarks on Economics Rules by Dani Rodrik, Journal of Economic Literature 55 (1), 162-172.

Sampson, T. (2017) Brexit: The economics of international disintegration Journal of Economic Perspectives, 31,(4), 163-184.

Scitovsky, T. (1958), Economic theory and Western European integration, Stanford, California; Stanford University Press.

Springford, Tilford, McCan, Whyte and Odendahl, (2016) The economic consequences of Leaving the EU, Centre for European Reform (CER), London; CER.

Stennett, A. (2016) The EU referendum and potential implications for Northern Ireland, Research and Information Research Paper, NIAR, 32-16, Belfast; Northern Ireland Assembly.

Streeten, P. (1961). Economic integration: aspects and problems. Leyden, Netherlands; A. W. Sythoff.

Swinney, P and Breach, A. (2017) The role of place in the UK's productivity problem, 
London: Centre for Cities.

Tomlinson, P.R. (2014) Industrial Policy in The Elgar Companion To Radical Political Economy. P. Arestis and M. Sawyer, (eds.). Cheltenham; Edward Elgar Publishing Ltd,

Van Reenen, J. (2011) Does Competition Raise Productivity Through Improving Management Practices? International Journal of Industrial Organization. 29 (3), 306 317.

Williamson, O. (2008) Outsourcing: Transaction Cost Economics and Supply Chain Management Journal of Supply Chain Management, 44 (2), 5-16.

Yeung, Henry Wai-chung (2017), Global production networks and foreign direct investment by small and medium enterprises in ASEAN', Transnational Corporations, 24(2), 1-42. 
Table 1: Snapshot of the rationale and relevance for cross-border collaboration (Ireland and Northern Ireland in bold)

\begin{tabular}{|c|c|c|}
\hline Driver & Explanation & $\begin{array}{l}\text { Relevance for } \\
\text { cross-border co- } \\
\text { operation }\end{array}$ \\
\hline \multirow[t]{4}{*}{ Economies of Scale } & \multirow{4}{*}{$\begin{array}{l}\text { Combine resources for efficiency of investment, larger } \\
\text { labour markets or access to wider business and } \\
\text { knowledge networks to increase critical mass; often used } \\
\text { to overcome peripherality. }\end{array}$} & Strong \\
\hline & & Moderate \\
\hline & & Weak \\
\hline & & Not Present \\
\hline \multirow[t]{4}{*}{ Political recognition } & \multirow{4}{*}{$\begin{array}{l}\text { Increase the recognition and strength of areas that are } \\
\text { far from capitals to better negotiate and compete for } \\
\text { resources from higher levels of government }\end{array}$} & Strong \\
\hline & & Moderate \\
\hline & & Weak \\
\hline & & Not Present \\
\hline \multirow[t]{4}{*}{ Complementarities } & \multirow{4}{*}{$\begin{array}{l}\text { Build on diversity of assets for research, technology and } \\
\text { economic base, as well as supply linkages }\end{array}$} & Strong \\
\hline & & Moderate \\
\hline & & Weak \\
\hline & & Not Present \\
\hline \multirow[t]{4}{*}{ Branding } & \multirow{4}{*}{$\begin{array}{l}\text { Increase internal recognition of the cross-border area as } \\
\text { well its external attractiveness to firms and skilled labour }\end{array}$} & Strong \\
\hline & & Moderate \\
\hline & & Weak \\
\hline & & Not Present \\
\hline \multirow[t]{4}{*}{ Border challenges } & \multirow{4}{*}{$\begin{array}{l}\text { Address the day-to-day challenges associated with flows } \\
\text { of people, goods and services (including public services } \\
\text { across the border }\end{array}$} & Strong \\
\hline & & Moderate \\
\hline & & Weak \\
\hline & & Not $\mathrm{Pr}$ \\
\hline
\end{tabular}

source: Nauwelaers, C. Maguire, K. and Marsan, G.A. (2013) 
Table 2: Northern Ireland exports and imports to and from Ireland by sector, 2015 (£ million)

\begin{tabular}{|l|c|c|}
\hline \multicolumn{1}{|c|}{ Product Sector } & $\begin{array}{c}\text { Exports: NI to } \\
\text { ROI }\end{array}$ & $\begin{array}{c}\text { Imports: NI from } \\
\text { ROI }\end{array}$ \\
\hline Food and live animals & 732 & 796 \\
\hline Beverages and tobacco & 116 & 73 \\
\hline Crude materials, inedible, except fuels & 88 & 114 \\
\hline Mineral fuels, lubricants and related materials & 54 & 89 \\
\hline Animal and vegetable oils, fats and waxes & 16 & 200 \\
\hline Chemicals and related products & 179 & 272 \\
\hline Manufactured goods classified chiefly by material & 374 & 918 \\
\hline Machinery and transport equipment & 259 & 209 \\
\hline Miscellaneous manufactured articles & 352 & 7 \\
\hline Commodities and transactions not elsewhere classified & 10 & $\mathbf{2 , 2 1 7}$ \\
\hline Total & $\mathbf{2 , 2 1 7}$ & \\
\hline
\end{tabular}

Source: Regional Trade Statistics, HRMC 2017 
Table 3: $\quad$ GDP annual growth rates for NI, UK and ROI pre and post-Brexit vote adjustments in parentheses $2014-18$ (\%)

\begin{tabular}{|c|c|c|c|c|c|c|c|c|c|c|}
\hline & \multicolumn{2}{|c|}{2014} & \multicolumn{2}{|c|}{2015} & \multicolumn{2}{|c|}{2016} & \multicolumn{2}{|c|}{2017} & \multicolumn{2}{|c|}{2018} \\
\hline & $\mathrm{NI}$ & UK & $\mathrm{NI}$ & UK & $\mathrm{Ni}$ & UK & $\mathrm{NI}$ & UK & $\mathrm{NI}$ & UK \\
\hline GDP growth & $\begin{array}{c}2.8 \\
(2.2)\end{array}$ & $\begin{array}{c}2.4 \\
(2.9)\end{array}$ & $\begin{array}{c}2.9 \\
(1.5)\end{array}$ & $\begin{array}{c}2.2 \\
(2.3)\end{array}$ & $\begin{array}{c}2.6 \\
(1.2)\end{array}$ & $\begin{array}{c}2.6 \\
(1.8)\end{array}$ & $\begin{array}{c}1.8 \\
(1.0)\end{array}$ & $\begin{array}{c}2.7 \\
(1.6)\end{array}$ & $\begin{array}{c}1.5 \\
(0.8)\end{array}$ & $\begin{array}{c}2.5 \\
(1.4)\end{array}$ \\
\hline $\begin{array}{l}\text { ROI GDP } \\
\text { growth }\end{array}$ & \multicolumn{2}{|c|}{$7.1(6.0)$} & \multicolumn{2}{|c|}{$6.7(7.8)^{12}$} & \multicolumn{2}{|c|}{$7.2(4.5)$} & \multicolumn{2}{|c|}{$7.7(3.3)$} & \multicolumn{2}{|c|}{$8.6(4.0)$} \\
\hline
\end{tabular}


Table 4: $\quad$ Potential Brexit Club Goods for Agriculture and Fisheries

\begin{tabular}{|c|c|c|c|c|}
\hline Club Good & $\begin{array}{c}\text { Financial } \\
\text { Contribution }\end{array}$ & $\begin{array}{c}\text { Impact from EU rules and } \\
\text { SEM access }\end{array}$ & $\begin{array}{l}\text { Influence } \\
\text { over EU } \\
\text { rules }\end{array}$ & $\begin{array}{l}\text { Transactions } \\
\text { Costs }\end{array}$ \\
\hline Current EU & $\begin{array}{l}0.6 \% \text { of GDP from } \\
\text { UK in } 2016 \text { but no } \\
\text { separate } \\
\text { contribution from NI }\end{array}$ & $\begin{array}{l}\text { Full access to SEM - no tariffs } \\
\text { or custom duties. Trade and air } \\
\text { route access negotiated at EU } \\
\text { level lowering transactions } \\
\text { costs for Member State. EU- } \\
\text { wide environmental practice. } \\
\text { Common agricultural and } \\
\text { fisheries policies standardising } \\
\text { product quality and market } \\
\text { access. Common external } \\
\text { tariffs to prevent anti- } \\
\text { competitive dumping (e.g. } \\
\text { steel) }\end{array}$ & $\begin{array}{l}\text { NI represented } \\
\text { through UK on } \\
\text { all institutions }\end{array}$ & Low \\
\hline $\begin{array}{l}\text { European } \\
\text { Economic } \\
\text { Area } \\
\text { (Norway) }\end{array}$ & $\begin{array}{l}\text { Contributes to EU } \\
\text { budget equivalent to } \\
0.34 \% \text { of UK GDP } \\
\text { (2016). But does not } \\
\text { contribute to } \\
\text { Common } \\
\text { Agricultural Policy } \\
\text { (CAP) }\end{array}$ & $\begin{array}{l}\text { Full access to SEM but EEA } \\
\text { agreement does not cover CAP } \\
\text { and CFP and customs union } \\
\text { and common trade policy } \\
\text { Matches EU rules and } \\
\text { standards on agriculture and } \\
\text { committed to process of } \\
\text { liberalising agricultural trade. } \\
\text { Some exemptions apply to } \\
\text { environmental regulations. Co- } \\
\text { operation between Norway and } \\
\text { EU in energy security and part } \\
\text { of SEM in energy. }\end{array}$ & $\begin{array}{l}\text { Right to } \\
\text { consultation } \\
\text { but not } \\
\text { represented in } \\
\text { EU } \\
\text { institutions }\end{array}$ & Fairly low \\
\hline $\begin{array}{l}\text { European } \\
\text { Free Trade } \\
\text { Area } \\
\text { (Switzerland) }\end{array}$ & $\begin{array}{l}\text { No obligation for } \\
\text { EFTA members to } \\
\text { contribute to EU } \\
\text { budget but } \\
\text { Switzerland } \\
\text { contributes } \\
\text { equivalent to } 0.11 \% \\
\text { of UK GDP. To cover } \\
\text { costs of } \\
\text { participation in } \\
\text { various programmes } \\
\text { including research }\end{array}$ & $\begin{array}{l}\text { Switzerland's agreement with } \\
\text { EU covers movement of } \\
\text { persons and access to SEM for } \\
\text { a number of sectors. } \\
\text { Passporting rights of Swiss } \\
\text { Banks operating in EU Member } \\
\text { States. Consultative role on } \\
\text { management of environment } \\
\text { rules and regulations. Not } \\
\text { covered by CAP with series of } \\
\text { bi-lateral trade agreements on } \\
\text { agricultural trade and lower } \\
\text { customs duties. Environmental } \\
\text { management based upon a } \\
\text { range of sectoral agreements }\end{array}$ & $\begin{array}{l}\text { No formal } \\
\text { right to be } \\
\text { consulted on } \\
\text { EU laws and } \\
\text { regulations }\end{array}$ & $\begin{array}{l}\text { Medium to } \\
\text { fairly high }\end{array}$ \\
\hline $\begin{array}{l}\text { Free Trade } \\
\text { Agreement } \\
\text { (Canada) }\end{array}$ & $\begin{array}{l}\text { The Comprehensive } \\
\text { Economic and Trade } \\
\text { Agreement (CETA) } \\
\text { between Canada has } \\
\text { been agreed but not } \\
\text { ratified but no } \\
\text { financial } \\
\text { contribution }\end{array}$ & $\begin{array}{l}\text { CETA gives Canada almost } \\
\text { complete access to the SEM } \\
\text { with the exception of financial } \\
\text { and other services. Joint } \\
\text { environmental and climate } \\
\text { protection but concerns over } \\
\text { GM product and carbon heavy } \\
\text { fuels that are not included. Up } \\
\text { to } 94 \% \text { of agricultural exports } \\
\text { form Canada will be tariff free. } \\
\text { Tariff free changes to some } \\
\text { fisheries product but food }\end{array}$ & $\begin{array}{l}\text { No formal } \\
\text { right to } \\
\text { influence EU } \\
\text { policies }\end{array}$ & High \\
\hline
\end{tabular}




\begin{tabular}{|c|c|c|c|c|}
\hline & & $\begin{array}{l}\text { safety and labelling missing } \\
\text { from agreement }\end{array}$ & & \\
\hline WTO & None & $\begin{array}{l}\text { EU is member of WTO with UK } \\
\text { having to negotiate separate } \\
\text { membership post-Brexit. WTO } \\
\text { exporters to EU have to } \\
\text { comply with environmental } \\
\text { regulations to access SEM. For } \\
\text { countries with WTO Most } \\
\text { Favoured Nation (MFN) status } \\
\text { the average tariff is } 5.4 \% \text { but } \\
\text { average agricultural tariff is } \\
12.2 \% \text {. Complex set of } \\
\text { arrangements covering } 6526 \\
\text { tariffs including fisheries. No } \\
\text { WTO rules in services }\end{array}$ & $\begin{array}{l}\text { No formal } \\
\text { powers }\end{array}$ & Very high \\
\hline
\end{tabular}

Source: adapted from Cave and Allen (2016) 


\section{Notes}

1 The term 'economic integration' however has a much shorter history; indeed, Machlup's classic survey (1977) could find no use of the term prior to 1942.

2 The use of the word co-operation encompasses trade exchanges and sector synergies. It also includes co-operation between universities and research institutes and economic development agencies to attract inward investment to the whole of Ireland. (See: InterTrade Ireland (2011) AgriFood: A Study for Cross-Border Co-Operation, Newry; Intertrade Ireland. Centre for Cross Border Studies A study of cross-border flows within the agri-food sector: A snapshot of four border counties, Armagh: Centre for Cross Border Studies. Farming Life £362,635 for new agri-food research projects, Farming Life: Portadown.

3 Transactions costs are defined by Kenneth Arrow as Kenneth Arrow defined transaction costs as "the costs of running the economic system" (1969, p.48). Effectively these costs are the administrative costs for a firm (costs of doing business) or organisation in undertaking primary activities.

${ }^{4}$ These costs appear to be rising exponentially as each stage of the negotiations between the European Commission and the UK government. They appear to have been given further impetus by the Confidence and Supply Agreement between the Democratic Unionist Party (DUP) and the UK government, exacerbated by the role of the DUP in the negotiations over regulatory equivalence between the two parts of Ireland.

5 The Sewell Convention was established in July 1998, the UK so that the Westminster Parliament would not normally legislate on devolved matters in Scotland, Wales and Northern Ireland without the consent of the Scottish Parliament, the Welsh Assembly or the Northern Ireland Assembly. The devolution settlement of that time meant that power was handed to the three nations, but sovereignty was retained by Westminster. The devolved administrations clearly must be consulted in the process of leaving the EU the consultation must be substantive. But as the Sewell Convention currently stands the devolved administrations, do not have a veto over Brexit (see Gallagher 2017, for details).

${ }^{6}$ It is clear that the electoral geography of Brexit is more complex as is the occupational, gender and age differences, In particular, the voting patterns of Brexit showed up sharp divisions between the territories of the UK in which two devolved nations: Northern Ireland and Scotland voted to remain in the EU (Sampson, 2017: 175-79).

7 In any case large public sectors can correspond with vibrant, successful small open economies (Rodrik, 1998). What the empirical evidence suggests is that $\mathrm{NI}$ is not unusual in having a large public sector, but it is unusual in not developing a sufficiently diverse and high performing export sector (Brownlow and Birnie, 2018).

${ }^{8}$ Most evidence on productivity points to the ownership structure and firm size being key determinants (Bloom and Van Reenan, 2010; Van Reenan, 2011, Swinney and Breach, 2017).

9 The J-Curve effect occurs when

10 One of the accounts of early commodity chains concerns shipbuilding between 1590 and 1790

in Europe in which the production of inputs changed (Gereffi, Korzeniewicz and Kozeniewicz, 199). Like today's supply chains, the production of these inputs was differentiated operationally and geographically. From C17th there was a marked specialisation in the building of naval and merchant ships, thereby creating new variants of commodity chains (Özveren, 1994, Williamson, 2008).

11 The Canadian company, Bombardier, produces the wings for its C-Series passenger jets: a crucial component of its GVC. In September 2017, the US Justice Department imposed a $220 \%$ tariff on each aircraft bough in the US. This was at the behest of the US aerospace firm, Boeing, on the basis that its sales to Delta was subsidized by the Canadian government against World Trade Organization (WTO) rules. In the event of the UK leaving the EU and moving to a WTObased trade regime the prospects for $\mathrm{NI}$ remaining a production locality may be under threat (Belfast Telegraph September 28 2017). 